\title{
ROLE OF FIIS IN INDIAN FINANCIAL MARKET
}

\section{Mr. Omer Fareed Mohammed* | Dr. S C Behl**}

*PhD Scholar, Himalayan University, Itanagar, Arunachal Pradesh, India.

**Research Supervisor, Himalayan University, Itanagar, Arunachal Pradesh, India.

DOI: http://doi.org/10.47211/idcij.2020.v07i03.012

Received $15^{\text {th }}$ June 2020, Accepted $25^{\text {th }}$ June 2020, Available online $10^{\text {th }}$ July 2020.

\begin{abstract}
:
Far reaching and rampant globalizations are clearly responsible for high economic spikes thereby resulting in cut throat competition and edgy innovations that are changing the dynamics of trade. Foreign Institutional Investments (FIls) are the measuring scale that determines accelerated economic development for many financial systems both in developing and developed economies. Flls have become an onus of global economic cooperation and integration. Developing countries like China, Korea etc have chronicled massive jump in economic stimulation since inducing FIIs in their economic policies. The USA is the leading developed country that is preferred by financial institutions for capital inflows but developing countries are also expanding their presence in the Fll market. Flls bring foreign capital investment to the national market and eases transfer of technological expertise, higher skills and knowledge, innovations and its corresponding tools. Indian policies to trigger foreign interests in its capital investment capacity encouraged some major players to enter the Indian capital market. Internal policies of the government like market cap, supply and demand, EPS and external determinants such as Flls, exchange rate stabilities, global economic changes have provided the much needed impetus to let the Flls thrive in the Indian financial market. The present paper outlines the role played by Flls in the Indian stock market providing statistical evidence of multi regression and coefficient correlation. Nifty and Sensex are the representative face of Indian stock market and the based on the performance of Indian stock market during the 11 years between 2001-2011, it can be deduced that Fll capital inflows were performing in tandem with Nifty and Sensex. With this research, we are concluding that FIl inflows to India were impacting the upward trend of the Indian capital market.
\end{abstract}

KEYWORDS: chronicled, deduced, impetus, onus, innovations, invigorated

\section{ABOUT AUTHORS:}

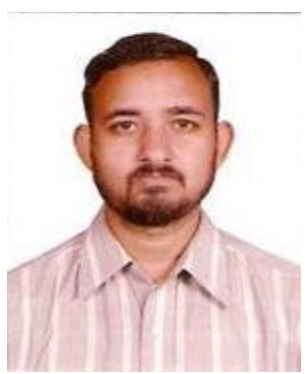

Author Mr. Omer Fareed Mohammed is working at Al Buraimi University College in Oman; He is pursuing Ph.D. from Himalayan University, Arunachal Pradesh, India. He has more than 18 years of teaching experience. He has attended various Seminars and conferences. His area of expertise covers the Corporate Finance, Stock Market Analysis, Forensic Accounting, Environmental Accounting, Personal Financial Planning, Auditing and Use of Information Technology in Accounting.

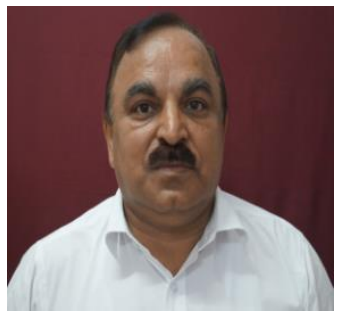

Author Dr. S C Behl is an active researcher with many publications in his name. He has 46 years' experience in Accounts, Finance, Audit, Personnel Management \& Admin in lower, Middle and HOD in Government and Private Sector He has attended and organised various National and International conferences and has given extensive lectures. 


\section{INTRODUCTION:}

Unbridled industrialization and easing of global trade has led to fast paced economic growth for many economies that led to a series of international innovations and accelerated competition among global players. Foreign institutional investments have become a benchmark for economic development in countries that seek to capture the international markets. As a result, Flls are becoming standard instrumental measure to face the stiff competition and achieve economic simulation and growth at international levels. Countries such as China, Korea and Singapore are registering remarkable accelerated rates of growth and development since the advent of financial institutions for trade and investment. Developing countries are still considered a lucrative market for investment by majority of global investors as it helps to consolidate economic growth for the parties involved and generate additional employment, investments and complex technological transfers to ease the trading activities.

When India opened the national market for trade in 1991, the government of India encouraged foreign markets to invest in the Indian Territory either directly or through the Flls. The trade policies eased investment compatibilities for the foreign investors that stimulated the economic activity in the country by an impressive foreign capital investment such that India became a lucrative and unexplored market for the international institutions. This resulted in a continuous and burgeoning flow of international trade in the country for the past 20 years.

When investment enters an international territory, it is called a foreign investment.

Therefore, a foreign investment from overseas is crucial as it encourages economic activity in the domestic capital investments and complements capital shortages that are so common in the case of developing countries. Ever since 1991, global investors are allowed to make investments in the Indian market in the form of stocks in listed corporations through the stock market and are therefore called as foreign institutional investments.

An investment of Fll status is considered an all pervasive and constructive investment for the whole economy as against a direct investment. In the case of direct investments, a single corporation or a market benefits by escalating its productivity, market share, its capacity or management control. On the other hand, FII investments are further invested into secondary markets to assist capital flow in the investment market rather than focusing on a section of capital enterprise. Turning an Fll investment to productivity depends on management decisions, production controls of the regional investor who designs production activities to invest the supplementary cash inflow through Flls and accelerate production.

Additional productivity decisions are not merely based on the inflow of foreign investments. It requires detailed planning and execution of designs drawn by the regional seller who then goes on to invest the sale proceeds to increase production capacity or market outreach and augment local production through foreign financial inflows. There is an underlying debate as to the predictability of the Fll investments as it creates volatility in foreign exchange rates and stock markets. This can be held true for individual investments as Flls are only relied as net capital inflows.

FIl investments not only bring financial assistance but also technological up gradation, governance controls and management practices. The sophisticated technological upgrade is far more critical in comparison to the finance. As many FIl investors prefer to seek high management controls, accountability and governance, this has led to transparent, tighter and credible practices by the listed Indian organizations.

Today Flls are considered a benchmark for mounting economic activities in the global circumstances. Developing countries like India liberalized their economic policies to accentuate investment opportunities in the domestic market and encourage capital investments by foreign sources. Developed countries usually prefer to invest in growing and nascent markets that have affordable labor markets, high scope for profits and a larger market for marketing their products. This in turn helps the foreign investors to expand exponentially along with the local economy.

A rapidly developing economy like India requires additional foreign capital support like Fll investments to develop its infrastructure and services like warehousing, seaports, railways and roads, insurance and banking services. To accelerate economic development and industrialization, India strengthened its capital investment opportunities for foreign investors since 1991 in various sectors that were previously off-limits.

Similarly, other developing economies have struggled to garner capital resources to strengthen its infrastructure in the absence of foreign assistance. Foreign capitalists are seen as a remedy to this scarce resource of finance for the countries that are seeking to make an impressionable growth in the global markets. The capital variations attract foreign enterprises to seek investment opportunities in the domestic capital market. Indian markets are known for attracting foreign investment due to the high interest rates compared to its developed counterparts. Developed countries have a lower range of interest rates spanning between1 
percent to 3 percent per annum while the Indian capital markets provide starkly high interest rates of 8 to 10 percent annually.

The Indian market facilitates a reduced capital expenditure for the foreign investment institutions. Investment institutions seek high return economies like India to maximize their return on investment whereby an increasing integration of international markets have created a volatile and increased dependence on Flls for growth and development by the growing economies.

\section{REVIEW OF LITERATURE:}

The balance of payment volatility was avoided in the 1990s when the political insecurities were growing by opening the protected economies. Mounting external debts and struggling economy along with trailing exports contributed to its underwhelming performance.

The Indian economists resorted to mortgaging its gold reserves and liberalizing the trade protection to encourage FDI investments in the economy. The resultant policies led to strengthening foreign investments interests to confide in the Indian financial markets.

The World Bank reported in 1997 that stock market performance improved considerably in the developing markets when foreign capital infusions increased.

Stanley Morgan (2002) studied Flls playing a substantial role in augmenting FOREX reserves thus enabling a string of economic developmental policies in India. The report suggests that FII considerably swayed the short term capital movements especially in the bear market. Even though the domestic behavior toward Flls was mediocre at best, Flls turned out to be a significant investment contributing the Indian economic growth. Meanwhile, the investment flow and returns on investment struggled during the bull market when domestic enterprises increased their participation thereby diminishing the FII influence. Morgan deduced that return on investment and foreign inflow correlation was elevated in the bear market leading to high equity performance and simulated domestic participation.

Chakrabarti, Agarwal studied the correlation of FII on equity returns and deduced that the impact was positively significant. Foreign investment institutions dominated the market profits where they bought financial assets when prices declined and increased its prices. Flls sold the acquired assets when the market prices were promising guaranteeing those profits and a dual directional relation of equity return and Flls.

Pasricha and Bansal summarized the effect on Indian stock market owing to nascent markets in relation to Flls. They examined the stability and stock market return changes following the advent of Flls in the domestic market and concluded that the average returns of Indian stocks registered minimal disturbance. After the Indian market opened its doors for foreign investments, the volatility became considerably stabilized.

John Andreas outlined the effect of FDIs on the host economy in his research. He postulated that FDI resulted in positive economic growth due to technological up gradation and capital transfusion. A research studied FDI inflows over 90 countries during 1980-2001 in emerging and flourishing economies.

He presumed that causality direction originated from FDI to the developing country's economic development and growth. In retrospect, FDI inflows could also augment due to a spike in economic growth activity of the host country. This impacts the host's capital market and entices the foreign institutions to invest substantially in the form of FDI. He concluded that FDI inflows and growth in invested economies are dependent mutually. On the other hand, it is difficult for low developing economies to seek foreign capital inflows when the market is struggling initially. Hence it is assumed that causality direction originates from foreign capital inflows to development and growth in the invested economies.

\section{CONCLUSION}

In conclusion, we can infer that FII presence in the Indian market invigorated the capital industry owing to healthy comprehensive competition, relaxation of global trade and practices, exchange of technology and optimal use of natural resources and factors of production. Flls have emerged as instrumental to India's infiltration and domination of the large-scale production organizations in a scenario where MNCs operate their affiliates throughout the world. Therefore, we can deduce that FII inflows are instrumental in development of the Indian capital markets.

\section{REFERENCES}

1. Stanley Morgan, "FII's influence on Stock Market", Journal: Journal of impact of Institutional Investors on ism. Vol 17. Publisher: Emerald Group Publishing Limited. 2002

2. Agarwal, R.N. (1997). "Foreign portfolio investment in some developing countries: A study of determinants and macroeconomic impact", Indian Economic Review, Volume, 32, Issue 2, pages 217-229.

3. Chakrabarti, Rajesh. (2001). "FII Flows to India: Nature and Causes."

4. Anand Bansal, \& J. S. Pasricha, Foreign Institutional Investors Impact on Stock Prices in India. Journal of Academics Research in Economics, 1(2), 181-189. 2009.

5. Johnson Andreas "The Effects of FDI Inflows on Host Country Economic Growth", 2004. 